\section{Protective Effects of Methanolic Fruit Extract of Solena amplexicaulis in Carbon Tetrachloride Induced Hepatotoxicity on Rat}

Parameshwar Hanwathe, Ravi Kumar Bobbala, Krishna Mohan Gottumukhala and *Narsimha Reddy Yellu

Department of Pharmacology and Toxicology

University College of Pharmaceutical Sciences, Kakatiya University, Warangal 506009, India.

\author{
*Corresponding Author \\ Dr. Narsimha Reddy Yellu \\ Department of Pharmacology \\ and Toxicology \\ University college of \\ Pharmaceutical Sciences, \\ Kakatiya University, Warangal \\ Andhra Pradesh-506 009. \\ India. \\ E-mail: ynrucpscku@gmail.com
}

Received - 29 June 2010

Accepted for Publication - 05 December 2010

\begin{abstract}
Herbal medicines derived from plant extracts are being increasingly utilized to treat a wide variety of clinical diseases. In the present study, the hepatoprotective activity of methanolic extract of the fruits of Solena amplexicaulis (Family, Cucurbitaceae) at doses of $250 \mathrm{mg} / \mathrm{kg}$ and $500 \mathrm{mg} / \mathrm{kg}$ body weight per oral were evaluated by carbon tetrachloride intoxication in rats. The toxic group which received Carbon tetrachloride $(1 \mathrm{ml} / \mathrm{kg}$ body weight per oral.) dissolved in 1:1 ratio in olive oil alone exhibited significant increase in serum alanine amino transferase, aspartate amino transferase, alkaline phosphatase and total bilirubin levels compared to the groups received pretreatment of Solena amplexicaulis per oral. The extract treated group remarkably controlled the aspartate amino transferase, serum alanine amino transferase, alkaline phosphatase and total bilirubin levels in serum and the effects were comparable with standard drug (silymarin $100 \mathrm{mg} / \mathrm{kg}$ body weight per oral). The histological examinations of the liver showed propound steatosis degeneration and nodule formation in the hepatic architecture of carbon tetrachloride treated rats. But the animals received pretreatment of the extract shown decreased necrotic zone and hepatocellular degeneration when compared to the liver exposed to carbon tetrachloride intoxication alone. This study suggests that methanolic extract of the fruit of Solena amplexicaulis has a liver protective effect against carbon tetrachloride-induced hepatotoxicity.
\end{abstract}

Key words: Carbon tetrachloride, Silymarin, Solena amplexicaulis, hepatoprotective activity, Biochemical parameter.

\title{
INTRODUCTION
}

The liver plays a major role in metabolism and has a number of functions in the body including glycogen storage, decomposition of red blood cells plasma protein synthesis and detoxification. It performs and regulates a wide variety of high-volume biochemical reactions requiring very specialized liver tissues (Anthea et al., 1993) restoring the various physiological processes in the body. Liver diseases are mainly caused by toxic chemicals, excess consumption of alcohol, infections and autoimmune disorders. Most of the hepatotoxic chemicals damage liver cells mainly by inducing lipid peroxidation and other oxidative damages. In general, liver is the organ which has the capability to regenerate itself. Inspite of tremendous advances in modern medicine, there are no effective drugs available that stimulate liver function. In absence of reliable liver protecting drugs in modern medicine, there are a number of medicinal preparations in Ayurveda recommended for the treatment of liver disorders and their usage is in vogue since centuries and are quite often claimed to offer significant relief (Shanmugasundaram et al., 2006). The plant Solena amplexicaulis (Lam.) Gandhi (syn: Melotheria heterophylla) belonging to Cucurbitaceae family are widely distributed in India, Srilanka, China and Taiwan. The tubers, leaves and seeds of the plant are extensively used in traditional system for various ailments like hepatosplenomegaly, spermatorrhoea, thermogenic, appetizer, cardiotonic, diuretics, haemorrhoids and invigorating (Kirtikar et al., 1988). The literature survey revealed that there are no scientific studies carried out regarding hepatoprotective activity of the fruits of $S$. amplexicaulis. Hence the present study is focused to evaluate the hepatoprotective potentials of the fruits against carbon tetrachloride induced liver injury in albino rats and the analyzed parameters included serum alanine amino 
transferase, aspartate amino transferase, alkaline phosphatase and total bilirubin, total protein, albumin levels and histopathology of liver damage.

\section{MATERIALS AND METHODS}

\section{Chemicals}

Silymarin from Micro labs. Ltd. Hosur (Bangalore), Carbon tetrachloride from S.D Fine chemicals Mumbai, Olive oil from Seven ships Hyderabad, Formaldehyde from S.D. Fine chemicals Mumbai, methanol from Ranbaxy laboratories, Mumbai, Normal Phase Pre-coated chromatographic Plates from Merck, Germany, ALT (Alanine transaminase), AST (Aspartate transaminase), ALP (Alkaline phosphate), TB (Total bilirubin), TP (Total protein) and ALB (Albumin) kits from Span, Diagnostics Ltd, Surat, India.

\section{Collection of Plant Material}

Unripe fruits of Solena amplexicaulis were collected from Pakkala, District, Warangal, Andhra Pradesh (India). The plant was authenticated by Prof. Raju S. Vastavaya, Department of Botany, Kakatiya University, Warangal, Andhra Pradesh (India) and a specimen voucher (C.No.1050/Param and V.S. Raju) was deposited for future reference.

\section{Preparation of plant extract}

The unripe fruits of the Solena amplexicaulis were air-dried and made into a coarse powder and extracted with 5 litre methanol by maceration. The crude extract was evaporated by using Rotavapour (BUCHI, Germany) under reduced pressure.

\section{Phytochemical Screening}

The methanolic fruit extract was subjected to preliminary phytochemical screening as per procedure to identify the presence of various phytoconstituents i.e. Alkaloids, Carbohydrates, Glycosides and Steroidal/Triterpenoidal compounds present in the extract (Kokate et al., 1997).

\section{Animals}

Female wistar albino rats (100-150 g) procured from M/S Mahaveera Enterprises, Hyderabad (India) were used for the studies. The animals were housed in large polypropylene cages in a temperature controlled room $\left(20^{\circ} \mathrm{C} \pm 2^{\circ} \mathrm{C}\right)$ and provided with standardized pellet feed and clean drinking water ad libitum. The study protocol was approved by the Institutional Animal Ethical Committee (IAEC).

\section{Hepatoprotective Studies}

The animals were divided into five groups of six animals in each as follows. Group-l: served as control and received $2 \%$ gum acacia ( $1 \mathrm{ml} / \mathrm{kg}$ p.o) daily for 7 days. Group-II: served as toxic and received $25 \%$ carbon tetrachloride in olive oil ( $1 \mathrm{ml} / \mathrm{kg} \mathrm{p.o)} \mathrm{daily} \mathrm{for} 7$ days. Group-III: served as standard (silymarin) and received (100 mg/kg body weight. per oral) daily for 7 days. Group-IV and Group-V were treated with methanolic extract of the fruits of Solena amplexicaulis at the dose of 250 and $500 \mathrm{mg} / \mathrm{kg}$ body weight per oral respectively for 7 days. On the $7^{\text {th }}$ day, except control, all groups received $25 \%$ carbon tetrachloride in olive oil 30 minutes after administration of the extract and silymarin (Gerhard Vogel et al., 1977).

\section{Biochemical estimation}

All the animals were anaesthetized with thiopental sodium $\left(60 \mathrm{mg} / \mathrm{kg}\right.$ i. p) and sacrificed on the $8^{\text {th }}$ day and blood was collected from the common carotid artery by carefully opening the neck region of the rat. The blood samples were allowed to coagulate at room temperature and the serum was separated at $3000 \mathrm{rpm}$ for 30 minutes by centrifugation. This was kept in frozen containers and proceeded for biochemical estimation of different parameters like serum alanine amino transferase, aspartate amino transferase (Reitman and Frankel, 1957), alkaline phosphatase (Tiez, 1983), total bilirubin (Gupta et al., 2007), total protein and albumin (Lowry et al., 1951) by their specific methods. 


\section{Histopathological examination}

The liver tissues were carefully dissected out and washed with $0.9 \%$ normal \pm saline solution and fixed in formalin (10\% Formaldehyde), dehydrated in gradual ethanol (50-100\%), cleared in xylene and embedded in paraffin, sections $(4-5 \mathrm{~mm}$ thick) were prepared and stained with hemotoxylin and Eosin dye for photomicorscopic observation.

\section{Statistical analysis}

The data were expressed by one-way analysis of variance (ANOVA) followed by Dunnett's t-test was applied for determining the statistical significance of difference between experimental groups.

\section{RESULTS AND DISCUSSION}

The crude extract of the fruits of Solena amplexicaulis indicated the presence of alkaloids, carbohydrates and steroids/terpenoids. The thin layer chromatography studies carried out also exhibited the $R_{f}$ values which coincide with the standards. The results of the hepatoprotective and histopathological studies are given in table 1 and figure 1 respectively. The administration of carbon tetrachloride induced acute liver damage which was well indicated by increased serum alanine amino transferase, aspartate amino transferase, alkaline phosphatase, total bilirubin and decreased total protein and albumin levels when compared with the control group. The methanolic fruit extract of Solena amplexicaulis at a dose of $500 \mathrm{mg} / \mathrm{kg}$ exhibited a significant decrease in the serum levels of serum alanine amino transferase $(P<0.001)$, aspartate amino transferase $(P<0.01)$, alkaline phosphatase and total bilirubin $(P<0.001)$. The levels of above enzymes were reduced significantly by the administration of extract in a dose dependent manner. The total protein $(P<0.001)$ and albumin $(P<0.01)$ levels were significantly increased when compared with the toxic group. The effect exhibited by Solena amplexicaulis 250 and $500 \mathrm{mg} / \mathrm{kg}$, group was comparable with the standard group treated with silymarin $(100 \mathrm{mg} / \mathrm{kg}$ body weight). The reference drug restored the altered levels of enzymes significantly $(p<0.001)$. The increased dose levels of Solena amplexicaulis exhibited an increase in efficacy which was reflected in the values of biochemical parameters and can be correlated with the results of histopathological studies.

Table 1: Effect of methanolic fruit extract of Solena amplexicaulis on the concentrations of serum hepatospecific enzymes, total bilirubin, total proteins and albumin.

\begin{tabular}{|c|c|c|c|c|c|c|}
\hline Groups & $\begin{array}{l}\text { ALT } \\
\text { (IU/L) }\end{array}$ & $\begin{array}{l}\text { AST } \\
\text { (IU/L) }\end{array}$ & $\begin{array}{l}\text { ALP } \\
\text { (IU/L) }\end{array}$ & $\begin{array}{l}\text { TBL } \\
\text { (mg/dl) }\end{array}$ & $\begin{array}{l}\text { TP } \\
\text { (mg/dl) }\end{array}$ & $\begin{array}{l}\text { ALB } \\
(\mathrm{mg} / \mathrm{dl})\end{array}$ \\
\hline $\begin{array}{l}\text { Group I } \\
\text { Control }\end{array}$ & $14.10 \pm 0.06$ & $11.10 \pm 1.20$ & $34.20 \pm 3.36$ & $3.15 \pm 0.08$ & $10.20 \pm 0.12$ & $7.50 \pm 0.13$ \\
\hline $\begin{array}{c}\text { Group II } \\
\text { Toxic } \\
\left(\text { Only } \mathrm{CCl}_{4}\right)\end{array}$ & $155.01 \pm 2.50$ & $144.5 \pm 2.03$ & $130.18 \pm 5.0$ & $9.09 \pm 0.40$ & $5.10 \pm 0.10$ & $1.54 \pm 0.20$ \\
\hline $\begin{array}{c}\text { Group III } \\
\text { (Standard/ } \\
\text { Silymarin + } \\
\left.\mathrm{CCl}_{4}\right)\end{array}$ & $40.50 \pm 3.20^{* * *}$ & $24.40 \pm 10.6^{* \star *}$ & $42.50 \pm 2.30^{* * *}$ & $4.01 \pm 0.08^{* * *}$ & $9.10 \pm 0.11^{* * *}$ & $6.94 \pm 0.10^{\star \star \star *}$ \\
\hline $\begin{array}{c}\text { Group IV } \\
(\text { SAME } 250+ \\
\left.\mathrm{CCl}_{4}\right)\end{array}$ & $90.10 \pm 9.01$ & $110.2 \pm 11.0$ & $115.5 \pm 1.00^{\star \star}$ & $8.93 \pm 0.09$ & $6.70 \pm 0.20$ & $4.02 \pm 0.19^{*}$ \\
\hline $\begin{array}{c}\text { Group V } \\
(\mathrm{SAME} 500 \\
\left.\mathrm{CCl}_{4}\right)\end{array}$ & $60.51 \pm 4.50^{* \star *}$ & $45.16 \pm 13.01^{* *}$ & $58.70 \pm 9.01^{* * *}$ & $5.92 \pm 0.03^{*}$ & $8.63 \pm 0.60^{* * t *}$ & $5.98 \pm 0.17^{* *}$ \\
\hline
\end{tabular}

$\mathrm{n}=6$, Data expressed as Mean \pm S.D, ${ }^{\star} P$ value $<0.05,{ }^{* \star} P$ value $<0.01,{ }^{\star \star *} P$ value $<0.001$ compared with toxic group. $\mathrm{ALT}=$ Alanine aminotransferase, $\mathrm{AST}=$ Aspartate aminotransferase, $\mathrm{ALP}=\mathrm{Alkaline}$ phosphatase, $\mathrm{TBL}=\mathrm{total}$ bilirubin, $\mathrm{TP}=$ Total proteins, $\mathrm{ALB}=\mathrm{Albumin}, \mathrm{SAME}=$ Solena amplexicaulis

The hepatotoxic agent carbon tetrachloride induces selective toxicity to the liver cells due to metabolic activation and this maintains them with semi-normal metabolic functions. Carbon tetrachloride is one of the most hepatotoxin experimental studies of liver diseases (Johnson et al., 1988). The hepatotoxic effects of carbon tetrachloride are largely due to its active metabolites, trichloromethyl radical (Srivastava et al., 1990). Due to the damage caused to hepatic cells, the leakage of plasma causing an increased levels of hepatospecific enzymes in serum. The elevated 
serum enzyme levels like alanine amino transferase and aspartate amino transferase are indicative of cellular leakage and disruption of cell membrane in liver (Drotman et al., 1978). Animal of group II (received carbon tetrachloride alone) significantly lost their body weight and showed reduced food consumption as compared to control. Animal group III (silymarin plus carbon tetrachloride treated), group IV and V (extract 250 and $500 \mathrm{mg} / \mathrm{kg}$ respectively plus carbon tetrachloride) showed a significant increase in body weight and food consumption when compared to group II. These findings suggest that extract administration has significantly neutralized the toxic effects of carbon tetrachloride and helped in regeneration of hepatocytes. Estimating the activities of serum marker enzymes like alanine aminotransferase, aspartate aminotransferase and alkaline phosphatase, bilirubin can make assessment of liver function. When liver cell plasma membrane is damaged, a variety of enzymes normally located in the cytosol are released in to the blood stream. Their estimation in the serum is a useful quantitative marker of the extent and type of hepatocellular damage.

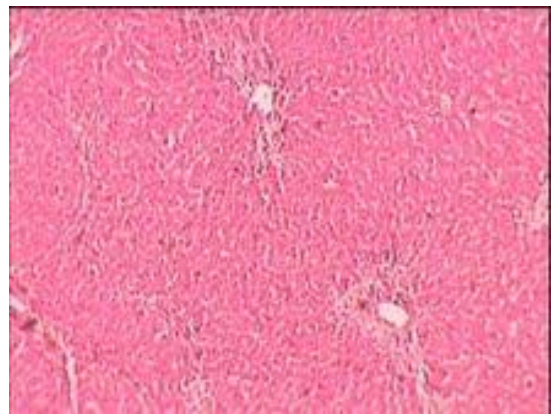

Figure 1.1: Section of liver with normal cell structure in Group I (Control)

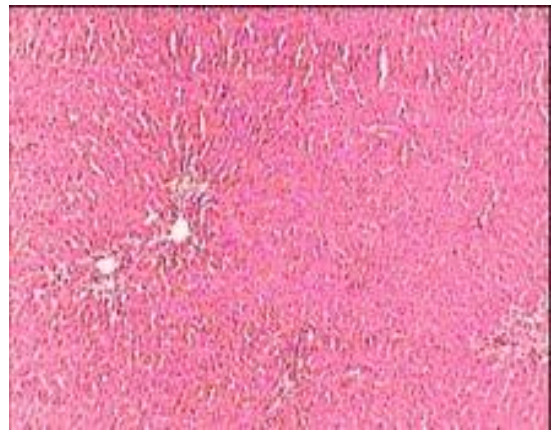

Figure 1.3: Section of liver showing lesser reduced necrotic area in Group III (standard- silymarin)

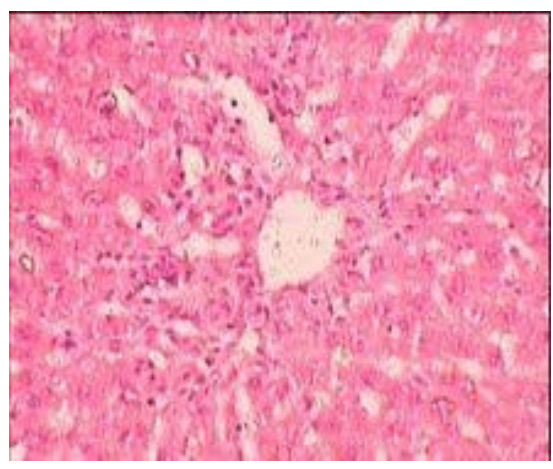

Figure 1.5: Section of liver showing significantly reduced necrotic area in Group V (SAME 500).

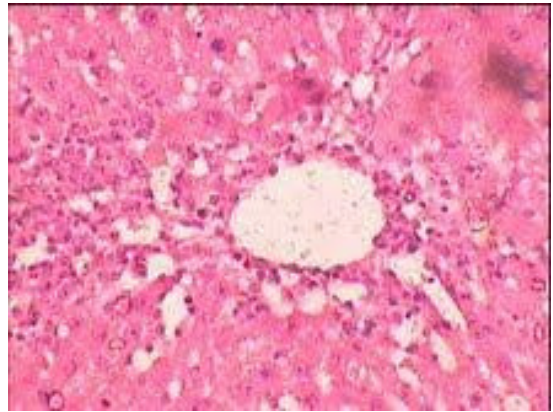

Figure 1.2: Section of liver showing necrosis in Group II (Toxic)

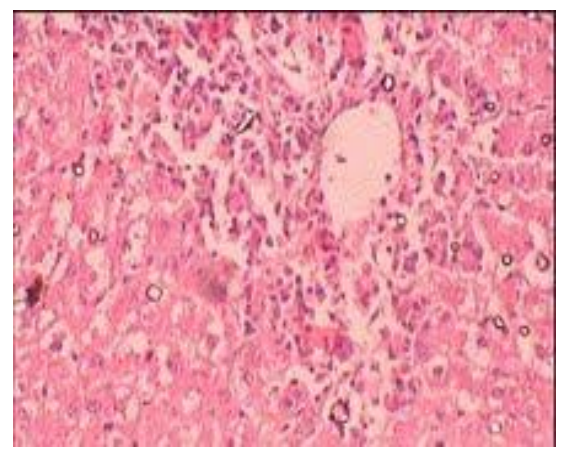

Figure 1.4: Section of liver showing area of necrosis in Group IV (SAME 250)

Figure 1: Sections of liver showing reduced necrotic area in standard and extract treated groups compared to toxic group.

STD=Standard (Silymarin), SAME=Solena amplexicaulis 
The hepatoprotective index of a drug can be evaluated by its capability to reduce the injurious effects or to preserve the normal hepatic physiological mechanisms which have been induced by hepatotoxin. The measurement of serum alanine amino transferase, aspartate amino transferase, alkaline phosphatase, total bilirubin levels serves as a means for the indirect assessment of condition of liver. The pretreatment of the animals with the extract 250 and $500 \mathrm{mg} / \mathrm{kg} \mathrm{p.o}$ remarkably reduced the serum alanine amino transferase, aspartate amino transferase, and alkaline phosphatase levels when compared with the toxic group. A high concentration of bilirubin in serum is an indication for increased erythrocyte degeneration rate. It also reflects the necrotic conditions of hepatocytes (Singh et al., 1998). The oral administration of Solena amplexicaulis at 250 and $500 \mathrm{mg} / \mathrm{kg}$ p.o reduced the serum total bilirubin levels. The total protein and albumin levels will be depressed in hepatotoxic conditions due to defective protein biosynthesis in liver (Clawson et al, .1989). The carbon tetrachloride intoxication causes disruption and disassociation of polyribosome on endoplasmic reticulum, thereby reducing the biosynthesis of protein. The pretreatment of Solena amplexicaulis might have reduced the polyribosome damage and this mechanism might have aided the protective effect. The histopathological studies are direct means for assessing the protective effect of the drug from liver injuries. The group which received carbon tetrachloride alone, the damage of cells around the central vein was well evident. Whereas, the intensity of damage was found lesser in the studies involved pretreatment of the methanolic extract of Solena amplexicaulis. The results of the histopathological studies support the hepatoprotective activity of the extract and can be correlated well with data obtained from evaluation of the biochemical parameters.

\section{CONCLUSION}

The above findings have shown that the methanolic extract of the fruits of Solena amplexicaulis contain some active phytoconstituents i.e Alkaloids, steroidal/triterpenoidal compounds and their glycosides and flavonoids which may be responsible for characteristic effect on hepatotoxicity.

\section{ACKNOWLEDGEMENT}

Authors are thankful to the Principal, Department of Pharmaceutical Sciences Kakatiya Univesity for providing research facilities for pharmacological activities. The authors are also thankful to Prof. V.S. Raju Department of Botany Kakatiya University for identification of plant material.

\section{REFERENCES}

Anthea M, Hopkins J, McLaughlin CW, Johnson S, Warner MQ, Lahart D. (1993), Human Biology and Health, Englewood Cliffs, New Jersey, USA; Pentice Hall.

Clawson GA. (1989), Mechanism of Carbon tetrachloride hepatotoxicity. Pathology and Immunopathology research. 8:104-112.

Drotman RB, Lawhorn GT. (1978), Serum enzymes as indicators of chemical induced liver damage. Drug Chem Toxicol. 1:163-171.

Gupta M, Mazumder UK, Thamil Selvan V, Manikandan L, Senthil Kumar GP, Suresh K, Kakotti BK (2007). Potential hepatoprotective effect and antioxidant role of methanol extract of Oldenlandia umbellate in carbon tetrachloride induced hepatotoxicity in wistar rats. Iranian J Pharmacol Thera. 6: 59.

Gerhard Vogel H. (2002), Drug discovery and evaluation: Pharmacological assays. $2^{\text {nd }}$ Ed. pp. 942-943, Heidelberg, Springer-Verlag.

Johnson DE, Kroening C. (1988), Mechanism of early carbon tetrachloride toxicity in cultured rat hepatocytes. Pharmcol Toxicol. 83:231-39.

Kirtikar KR, Basu BD. (1988), Indian Medicinal plants Vol.-II: $3^{\text {rd }}$ Ed. pp. 1162- 1163.

Kokate CK, Purohit AP, Gokhakle SB. (1997), Analytical Pharmacognosy, $5^{\text {th }}$ Ed. pp. 119-37, Nirali Prakashan, India.

Lowry OH, Rosebrough NJ, Farr AL, Randall RJ. (1951), Protein measurement with Folin Phenol reagent. J Biol Chem. 193: 265-75. 
Reitman S, Frankel AS. (1957), A colorimetric method for the determination of serum glutamic oxaloacetic and glutamate pyruvate transaminase. Am J Clin Path. 28: 53- 56.

Shanmugasundaram P, Venkataraman S. (2006), Hepatoprotective and antioxidant effect of Hygrophila auriculata (K.Schum) Heine Acanthaceae root extract. Journal of Ethno Pharmacology. 104:124-28.

Srivastava SP, Chen NO, Hotlzman JL. (1990), The In vitro NADPH dependent inhibition by Carbon tetrachloride of the ATP dependent calcium uptake of hepatic microsomes from male rats. Studies on the mechanism inactivation of the hepaticmicrosomal calcium pump $\mathrm{CCl}_{4}$ radical. J Biol. Chem. 265:8392-99.

Singh B, Saxena, AK.Chanda BK. Anand KK, Suri OP, Suri KA, Satti NK. (1998), Hepatoprotective activity of verbenalin on experimental liver damage in rodents. Fitoterepia. 69:135-140.

Tiez NW. (1983), Study group on alkaline phosphatase: A reference method of measurement of alkaline phosphatase activity in human serum. Clin Chem. 29:751-55. 